\title{
Taxonomic Significance of Glume Morphology and Leaf Epidermal Characteristics in some Taxa of Tribe Aveneae (Poaceae)
}

\author{
Adel EL-GAZZAR ${ }^{1}$, Monier Abd El-GHANI ${ }^{2 *}$, Lamiaa SHALABI ${ }^{3}$ \\ ${ }^{1}$ Suez Canal University, Faculty of Education at El-Arish, Department of Biological and Geological Sciences, N. Sinai, Egypt \\ ${ }^{2}$ Cairo University, Faculty of Science, The Herbarium, Botany Department, Giza 12613, Egypt; mmabdelghnai@gmail.com (*orresponding author) \\ ${ }^{3}$ Ain Shams University, Faculty of Education, Department of Biological and Geological Sciences, Cairo, Egypt
}

\begin{abstract}
The numerical classification of tribe Aveneae (Poaceae) is discussed regarding the glume morphology and silica skeleton morphologies. The present study dealt with 18 species belonging to 10 genera of the tribe to cover as many groups as possible within Aveneae. The total of 31 structural characters and 71 character states were scored comparatively. The resulted data matrix was analyzed under a combination of Euclidean distance measure and Ward's clustering method included in the program package PC-ORD version 5 . The resulted dendrogram separated the tribe into five basic sub-ordinate groups created from three major groups A, B and C. The taxonomic significance of these results was discussed. The results showed congruence between the clustering and PCA method, in suggesting three major groups and 5 sub-ordinate groups.
\end{abstract}

Keywords: Aveneae, morphology, numerical analysis, phytoliths, Poaceae, silica bodies, taxonomy

\section{Introduction}

Tribe Aveneae [Dumort., Observ. Gramin. Belg., 82:1824] including Agrostideae [Dumort., Observ. Gramin. Belg., 83:1824] is the second largest tribe in subfamily Pooideae Benth., and is one of the main groups of the grass family Poaceae (R. Br.) Barnhart. It includes about 73 genera and 1050 species (APG III, 2009) mainly found in temperate regions of both hemispheres and extends to mountainous regions of the tropics (Clayton, 1975, 1981; Clayton and Renvoize, 1986; MacFarlane, 1987; MacFarlane and Watson, 1980, 1982; Mitra and Mukherjee, 2005; Stebbins, 1956; Stebbins and Crampton, 1961; Watson and Dallwitz, 1992). It characterized by laterally compressed spikelets with one to several fertile florets, rachilla usually disarticulating above glumes; glumes persistent, often equal to spikelet or at least longer than first floret.

In Egypt, Aveneae includes 14 genus and 33 species (Boulos, 2005; Täkholm, 1974), mostly herbaceous, growing on wide range of habitats such as desert, wetlands, farmlands and salt marshes. Phalaris is the largest genus (6 specie), followed by Avena and Rostraria ( 5 species for each). Seven monospecific genera include Holcus, Agrostis, Ammophila, Triplanche, Gastridium, Lagurus and Alopecurus.

Aveneae is a large heteromorphous tribe, in which different genera show morphological variations, but species within the genus are quite similar morphologically, e.g the genus Polypogon and Avena. In addition, Agrostis viridis seems quite similar to genus Polypogon and there is confusion in identifying Polypogon monospeliensis from $P$. fugax and Avena fatua from A. ludoviciana, so has posed many problems to the taxonomists using gross morphology alone (Strivastava, 1978). So, in this work, glume morphology beside foliar epidermal characters, especially silica skeleton, will assist to elucidate taxonomic relationships at different levels in tribe Aveneae.

Clayton and Renvoize (1986) employed the first tribal name Aveneae, with four recognized subtribes Duthieinae, Aveninae, Phalaridinae and Alopecurinae. Aveneae classification and its taxonomical borders with its sister tribe Poeae R. Br. have varied historically depending on an author's interpretations of the tribe's morphologic heterogeneity; consequently, the a description of many of its genera has been problematical (Tab. 1).

In different classifications, Aveneae have been separated from Poeae based on the floral traits cited (Clayton and Renvoize, 1986; MacFarlane and Watson, 1982; Tzvelev, 1976; Watson and Dallwitz, 1992). Tzvelev (1989), however, did not recognize Aveneae but transferred their members to the large tribe Poeae, although Phleeae Dumort. (Including Phalarideae Kunth) was separated from Poeae.

An increasing number of numerical classification studies in recent decades have helped to clarify taxonomic relationships within the subfamily Pooideae including tribe Aveneae (Catalan et al., 1997; Davis and Soreng, 1993; Grit and Röser, 2006; Grit et al., 2009; GPWG, 2001; Hsiao et al., 1995; Nadot et al., 1994; Quintanar et al, 2007; Soreng et al., 1990). However, the classification of Aveneae 
has remained largely problematic, some taxonomic treatments related to the avenoids have focused on particular genera, like Trisetum (Edgar, 1998; Randall and Hilu, 1986), Helictotrichon (Grebenstein et al., 1998), Avena (El-Rabey, 2008; Peng et al., 2010; Rodionov et al., 2005), Deschampsia (Chiapella, 2007), Anthoxanthum (Pereira et al., 2007), Alopecurus (Dogan, 1999), Phleum (Scholz, 1999), and Calamagrostis (Hai-Ying et al., 2006).

Foliar epidermal characters as an aid to the identification and classification of tribe Aveneae was the subject of many works (Ahmad, et al., 2011; Hai-Ying et al., 2006; Xinming et al., 1998), but focusing on silica skeleton morphologies of the epidermis have never been studied previously in tribe Aveneae. Silica in the form of bodies or particles deposited within or on cells of living plant leaves, in addition to silica incorporated in cell walls or completely filling hairs and other plant tissues composed silica skeleton of the plant (Arimura and Kanno, 1958). The silica skeleton may represent a potentially significant taxonomic character and may be diagnostic to subfamilies and genera, that a strong genetic influence governs formation of silica bodies. In other words, families and orders of plants show strong tendencies to silicify or not silicify their tissues (Barthlott et al., 1998; Brown, 1984; Cai and Wang, 1994; Davila and Clark, 1990; Ellis, 1979; Fredlund and Tieszen, 1994; Mejia and Bisbey, 2003; Metcalfe, 1960; Mulholland, 1989; Mulholland and Rapp, 1992; Palmer and Tucker, 1981; Palmer et al., 1985; Piperno, 1988; Stebbins, 1956; Twiss et al., 1969). So this work aimed to study the glumes macromorphology combined with silica skeleton morphology as taxonomic tools in the numerical classification of tribe Aveneae in the flora of Egypt.

\section{Material and methods}

\section{Taxon sample}

On the basis of previous classifications (Tab. 1) and molecular studies focused on Pooideae or Aveneae (Catalan et al., 2004; Davis and Soreng, 2007; Soreng and Davis, 2000), the taxon sample was selected to cover as many groups as possible within Aveneae (i.e. subtribes Aveninae, Agrostidinae, Phalaridinae and Alopecurinae). The study dealt with 18 species belonging to 10 genera of the tribe (Tab. 2), specimens were collected as dried materials from the Cairo University Herbarium (CAI).

\section{Observations of characters}

The total of 31 structural characters and 71 character states were scored, of which 8 were morphological with 25 character states and 23 were anatomical with 63 character states. For morphometric analyses, 5-10 individuals from each taxon were studied. The morphological characters were concerned with glumes, chosen due to experience of authors and previous studies. The anatomical characters were covered the silica skeleton features of the leaf epidermis (Tab. 3), characters were selected based on those reported by Piperno and Pearsall (1998), Bowdery et al. (2001), Madella et al. (2005), and Honaine et al. (2006). The character states were recorded in the data matrix (Tab. 4) to show the distribution of characters among the species examined from tribe Aveneae, to be ready for numerical analyses.

Leaf blades of the specimens have been prepared for describing the silica skeleton morphology found in tissues of central part of the middle of leaf. There are several methods currently established for investigating the pattern of plant silica skeleton. The theory is: silica is acidic in nature, very resistant to oxidation (unlike pollen, but quite like diatoms). Wet, dry, or combined oxidation techniques are commonly used (Clark, 1960; Theunissen, 1994). Before oxidation, leaves and culms of each species have to be cut into small pieces and pre-washed to remove dust particles. After digestion of organics with strong oxidizing agent, hydrogen peroxide, (for 24 hours), residue has to be treated with hydrochloric acid (for 2 hours) to remove carbonates, and washed by distilled water. The obtained samples were stained using safranin, light green dyes or both in double staining technique. Then samples were mounted onto microscopic slides in canada balsam medium for photomicrography. Light photomicrography at $\times 400$ magnification was used to describe silica skeleton.

\section{Data analysis}

In order to group the species having structural similarities, the data matrix (Tab. 4) was subjected to numerical analysis under four different combinations of two dissimilarity assessment methods (Euclidean and Relative Euclidean) and two clustering methods with high clustering intensity (Ward's method and Flexible Beta -0.25) included in the program package PC-ORD version 5 for Windows (McCune, 1997). Other combinations in this package were either mathematically incompatible or yielded taxonomically unacceptable dendrograms with obvious tailing problems.

Principal component analysis (PCA) was performed for the studied samples based on the examined 31 characters using Multivariate Statistics Package (MVSP) version 3.13 for Windows (Kovach, 1999).

\section{Result and discussion}

Fig. 1 shows the dendrogram based on analysis of 31 characters listed in (Tab. 3) and recorded comparatively for 18 species belonging to 10 genera of tribe Aveneae and analyzed under a combination of Euclidean distance measure and Ward's clustering method. The tree was separated into five basic sub-ordinate groups $(1,2,3,4$ and 5$)$. The sub-ordinate groups 1 and 2 were resulted from the first major group A, while the sub-ordinate group 3 was resulted from the second major group $\mathrm{B}$, but the sub-ordinate groups 4 and 5 were resulted from the third major group C (Fig. 1) 
Tab. 1. Placement of the Aveneae representatives included in our study in selected classification systems

\begin{tabular}{|c|c|c|c|c|c|c|c|c|c|c|c|}
\hline $\begin{array}{c}\text { Ascherson } \\
\text { and Graebner } \\
(1898-1902)\end{array}$ & $\begin{array}{l}\text { Schaffner } \\
(1912)\end{array}$ & $\begin{array}{l}\text { Maire et al. } \\
\quad(1953)\end{array}$ & Prat (1960) & $\begin{array}{l}\text { Tzvelev } \\
(1976)\end{array}$ & $\begin{array}{l}\text { Tutin et al. } \\
\text { (1980) }\end{array}$ & $\begin{array}{c}\text { Conert } \\
(1983-1992)\end{array}$ & $\begin{array}{c}\text { Clayton and } \\
\text { Renvoize } \\
(1986)\end{array}$ & $\begin{array}{c}\text { Watson and } \\
\text { Dallwitz } \\
(1992) \\
\end{array}$ & $\begin{array}{l}\text { GPWG } \\
(2001)\end{array}$ & $\begin{array}{l}\text { Soreng et al. } \\
(2003-2007)\end{array}$ & $\begin{array}{c}\text { Mabberley } \\
(2008)\end{array}$ \\
\hline & & & & & & & & & Poeae & Poeae & Poeae \\
\hline & & & & & & & & & & & Polypogon \\
\hline \multirow[t]{2}{*}{ Aveneae } & Aveneae & Aveneae & Aveneae & Aveneae & Aveneae & Aveneae & Aveneae & Aveneae & & & Aveneae \\
\hline & & Aveninae & & Aveninae & & Aveninae & & & & Aveninae & Aveninae \\
\hline \multirow[t]{4}{*}{ Avena } & Avena & Avena & Avena & Avena & Avena & Avena & Avena & Avena & Avena & Avena & Avena \\
\hline & & Rostraria & Rostraria & Rostraria & Rostraria & & Rostraria & Rostraria & Rostraria & Rostraria & \\
\hline & Trisetaria & & & & & Trisetaria & & & & Trisetaria & Trisetaria \\
\hline & & & & & & & & & & Lagurus & \\
\hline \multirow[t]{2}{*}{ Agrostideae } & Agrostideae & Agrostideae & Agrostideae & & & & & & & & \\
\hline & & Agrostidinae & & Agrostidinae & & Agrostidinae & Alopecurinae & & & Agrostidinae & Alopecurinae \\
\hline \multirow[t]{2}{*}{ Agrostis } & Agrostis & Agrostis & Agrostis & Agrostis & Agrostis & Agrostis & Agrostis & Agrostis & Agrostis & Agrostis & Agrostis \\
\hline & Ammophila & Ammophila & Ammophila & Ammophila & Ammophila & & Ammophila & Ammophila & Ammophila & Ammophila & \\
\hline Lagurus & & Lagurus & Lagurus & Lagurus & Lagurus & Lagurus & Lagurus & Lagurus & & & \\
\hline \multirow[t]{2}{*}{ Polypogon } & Polypogon & Polypogon & Polypogon & Polypogon & Polypogon & Polypogon & Polypogon & Polypogon & Polypogon & Polypogon & \\
\hline & & & & Pbleeae & & & & & & & \\
\hline Phleinae & & Pbleinae & & Alopecurinae & & & & & & Alopecurinae & \\
\hline \multirow[t]{2}{*}{ Alopecurus } & Alopecurus & Alopecurus & Alopecurus & Alopecurus & Alopecurus & & Alopecurus & Alopecurus & Alopecurus & Alopecurus & Alopecurus \\
\hline & & & & Phleinae & & & & & & & \\
\hline Pbleum & Pbleum & Phleum & Phleum & Pbleum & Phleum & & Pbleum & Pbleum & Pbleum & Pbleum & Phleum \\
\hline \multirow[t]{2}{*}{ Phalarideae } & Phalarideae & Phalarideae & Phalarideae & Phalarideae & & Phalarideae & & & & & \\
\hline & & & & Phalaridinae & & & Phalaridinae & & & Phalaridinae & Phalaridinae \\
\hline Phalaris & Phalaris & Phalaris & Phalaris & Phalaris & Phalaris & Phalaris & Phalaris & Phalaris & Phalaris & Phalaris & Phalaris \\
\hline
\end{tabular}


Tab. 2. The taxon sample and taxa abbreviations used in the numerical analysis of tribe Aveneae, Poeaceae (According to Boulos, 2005)

\begin{tabular}{|c|c|c|}
\hline No. & Taxa & Abbreviations \\
\hline 1 & Agrostis stolonifera $\mathrm{L}$. & Agrost \\
\hline 2 & Alopecurus myosuroides Huds. & Alopec \\
\hline 3 & Ammophila arenaria (L.) Link & Ammoph \\
\hline 4 & Avena barbata Pott ex Link & A barb \\
\hline 5 & A. fatua $\mathrm{L}$. & A fatu \\
\hline 6 & A. sativa $\mathrm{L}$. & A sati \\
\hline 7 & A. sterilis $\mathrm{L}$. & A ster \\
\hline 8 & Lagurus ovatus $\mathrm{L}$. & Laguru \\
\hline 9 & Phalaris minor Retz. & P mino \\
\hline 10 & P. paradoxa L. & P para \\
\hline 11 & Phleum pratense $\mathrm{L}$. & Ph pra \\
\hline 12 & $\begin{array}{l}\text { Ph. subulatum (Savi) } \\
\text { Asch. \& Graebn. }\end{array}$ & $\mathrm{Ph}$ sub \\
\hline 13 & Polypogon maritimus Willd. & Po mar \\
\hline 14 & P. monospeliensis (L.) Desf. & Po mon \\
\hline 15 & P. viridis (Gouan) Breistr. & Po vir \\
\hline 16 & Rostraria cristata (L.) Tzvelev & Rostra \\
\hline 17 & Trisetaria glumacea (Boiss.) Maire & T glum \\
\hline 18 & T. linearis Forssk. & Tline \\
\hline
\end{tabular}

The sub-ordinate group 1 comprised three species; Agrostis stolonifera, Rostraria cristata and Trisetaria glumacea. These species were quite similar in unequal lanceolate glumes with acute apex and one-nerved lower glumes, at the same time, the three species have a trapezoid silica bodies with flat ends and length more than 3 times as broad (Plate1; 1, 16 and 17). But Agrostis stolonifera differ in some characters from the other two species, which made it separated monophyletically from them, i.e. having 1-flowered inflorescence, absence of macrohairs and presence of irregular bilobate and trilobite silica bodies (Plate $1,1)$.
The sub-ordinate group 2 included the two Phalaris species; $P$. minor and P. paradoxa as a monophyletic group, these species were similar in all recorded characters except the glumes shape oblanceolate with acuminate apex in $P$. minor, but glumes were lanceolate with acute apex in $P$. paradoxa. The monophyletically aspect of this group reflects the separation of genus Phalaris in a separate subtribe Phalaridineae under tribe Aveneae or Poeae, while other classifications placed genus Phalaris in a separate tribe Phalarideae as illustrated in Tab. 1. This result goes with that reported by Quintanar et al. (2007) through using the Plastid trnT-F and nuclear ribosomal ITS sequences to reconstruct the phylogeny of the Aveneae-PoeaeSeslerieae complex, and another similar study by Saarela et al. (2010).

The sub-ordinate group 3 encompasses six species; Lagurus ovatus, the three Polypogon species, P. maritimus, P. monospeliensis and P. viridis and the two Phleum species, $\mathrm{Ph}$. pratense and Ph. subulatum. The placement of these species in one group agrees with the majority of classification systems as shown in (Tab. 1). These species were grouped according to the relative similarity in the 1-flowered inflorescence, the hairy awened glumes, as well as the trapezoid silica bodies with flat ends with length more than 3 times as broad (Plate 1; 8 and 11-15). It is clear from the dendrogram (Fig. 1) that Polypogon maritimus and $P$. monospeliensis appeared very close to each other and seemed to be one species, that they were similar in all recorded characters, which needs further study using wider characters. At the same time, the two Phleum species (Ph. pratense and $\mathrm{Ph}$. subulatum) appeared in a close innergroup far from the other four species of the sub-ordinate group 3; this is due to the similarity between each other and the differences with other species within the same sub-group, such as unequal 3-nerved glumes and presence of irregular bilobate silica bodies.

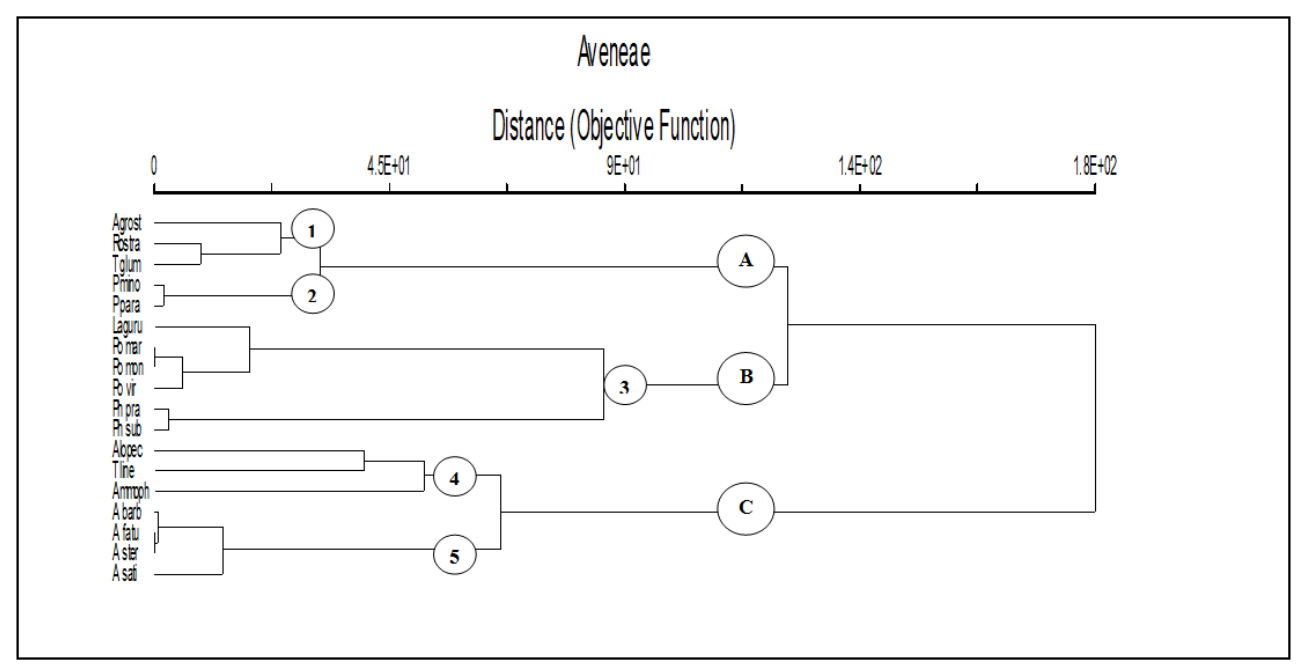

Fig. 1. Dendrogram of Aveneae based on analysis of characters recorded in Tab. 4 under a combination of Euclidean distance measure and Ward's clustering method. \% chaining $=3.19 \%$ 
Tab. 3. Characters and character states used in numerical analysis of tribe Aveneae

\begin{tabular}{|c|c|c|c|}
\hline No & Characters & Character states & Code \\
\hline \multirow{2}{*}{$\mathrm{C} 1$} & \multirow{2}{*}{ Number of flowers in spikelets } & 1-flowered & 1 \\
\hline & & several-flowered & 0 \\
\hline \multirow{2}{*}{$\mathrm{C} 2$} & \multirow{2}{*}{ Similarity of glumes in length } & equal & 1 \\
\hline & & unequal & 0 \\
\hline \multirow{4}{*}{ C3 } & \multirow{4}{*}{ Glumes shape } & lanceolate & 1 \\
\hline & & oblanceolate & 2 \\
\hline & & elliptic & 3 \\
\hline & & oblong & 4 \\
\hline \multirow{4}{*}{$\mathrm{C} 4$} & \multirow{4}{*}{ Glume apex } & acute & 1 \\
\hline & & acuminate & 2 \\
\hline & & aristulate & 3 \\
\hline & & awned & 4 \\
\hline \multirow{3}{*}{ C5 } & \multirow{3}{*}{ Glume surface } & glabrous & 1 \\
\hline & & hairy & 2 \\
\hline & & spiny & 3 \\
\hline \multirow{3}{*}{$\mathrm{C} 6$} & \multirow{3}{*}{ Glume length (mm) } & $1.5-3.9$ & 1 \\
\hline & & $4-10.9$ & 2 \\
\hline & & $11-30$ & 3 \\
\hline \multirow{4}{*}{$\mathrm{C} 7$} & \multirow{4}{*}{ Number of veins in lower glume } & 1 & 1 \\
\hline & & 2 & 2 \\
\hline & & 3 & 3 \\
\hline & & $7-9$ & 4 \\
\hline \multirow{3}{*}{$\mathrm{C} 8$} & \multirow{3}{*}{ Number of veins in upper glume } & 1 & 1 \\
\hline & & 3 & 2 \\
\hline & & $7-9$ & 3 \\
\hline \multirow{2}{*}{ C9 } & \multirow{2}{*}{ Spiral thickening of xylem vessels } & present & 1 \\
\hline & & absent & 0 \\
\hline \multirow{2}{*}{$\mathrm{C} 10$} & \multirow{2}{*}{ Annular thickening of xylem vessels } & present & 1 \\
\hline & & absent & 0 \\
\hline \multirow{2}{*}{$\mathrm{C} 11$} & Fnidermal lono cellc. parnlel walls & thickened & 1 \\
\hline & Epidermal long cells: parallel walls & not thickened & 0 \\
\hline C12 & Fnidermal lono cells. parallel walls shane & undulate & 1 \\
\hline & & straight & 0 \\
\hline $\mathrm{C} 13$ & Bulliform cells & silicified & 1 \\
\hline C15 & Bulliform cells & not silicified & 0 \\
\hline$C 1 /$ & Stomol chacidionucllc & oblong & 1 \\
\hline C14 & Stomatal subsidiary cells & triangular & 0 \\
\hline$C 15$ & Fnidermol nonilhe & present & 1 \\
\hline (1) & Epıdermal papillae & absent & 0 \\
\hline C16 & Hooked prickle hairs & present & 1 \\
\hline C16 & Hooked prickle hairs & absent & 0 \\
\hline C17 & & present & 1 \\
\hline C17 & Straight prickle hairs & absent & 0 \\
\hline C18 & Macrobairs & present & 1 \\
\hline C18 & Macro haurs & absent & 0 \\
\hline$C 19$ & Irrecular bilobate silica bodies & present & 1 \\
\hline (19 & Irregular bilobate silica bodies & absent & 0 \\
\hline C20 & Trilobate silico bodies & present & 1 \\
\hline $\mathrm{C} 20$ & Irilobate silica bodies & absent & 0 \\
\hline & & present & 1 \\
\hline $\mathrm{C} 21$ & Elongate smooth silica bodies & absent & 0 \\
\hline
\end{tabular}


Tab. 3. Characters and character states used in numerical analysis of tribe Aveneae (cont.)

\begin{tabular}{lccc}
\hline C22 & Trapezoid silica bodies & present & 1 \\
absent & present & absent & 1 \\
C23 & Narrow elliptic silica bodies & $\begin{array}{c}\text { sinuous-wavy } \\
\text { straight }\end{array}$ & 0 \\
\hline C24 & Side walls of silica bodies & present & 1 \\
\hline C25 & Silica bodies with concave ends & absent & 1 \\
\hline C26 & Silica bodies with convex ends & present & 0 \\
\hline C27 & Silica bodies with flat ends & absent & 1 \\
\hline C28 & Silica bodies with pointed ends & present & 0 \\
\hline absent & present & 0 \\
\hline C30 & Silica bodies $>3$ times as long as width & absent & 1 \\
\hline C31 & Silica bodies $<3$ times as long as width & present & 0 \\
\hline
\end{tabular}

Tab. 4. Distribution of characters among Aveneae species for species abbreviations, see Tab. 2

\begin{tabular}{|c|c|c|c|c|c|c|c|c|c|c|c|c|c|c|c|c|c|c|c|c|c|c|c|c|c|c|c|c|c|c|c|}
\hline \multirow{2}{*}{$\begin{array}{c}\text { Species } \\
\text { Abbreviations }\end{array}$} & \multicolumn{31}{|c|}{ Character states } \\
\hline & 1 & 2 & 3 & 4 & 5 & 6 & 7 & 8 & 9 & 10 & 11 & 12 & 13 & 14 & 15 & 16 & 17 & 18 & 19 & 20 & 21 & 22 & 23 & 24 & 25 & 26 & 27 & 28 & 29 & 30 & 31 \\
\hline Agrost & 1 & 0 & 1 & 1 & 3 & 1 & 1 & 1 & 1 & 1 & 0 & 0 & 0 & 1 & 0 & 1 & 1 & 0 & 1 & 1 & 0 & 1 & 0 & 1 & 1 & 0 & 1 & 1 & 1 & 1 & 0 \\
\hline Alopec & 1 & 0 & 1 & 1 & 2 & 1 & 4 & 2 & 1 & 0 & 0 & 0 & 1 & 1 & 1 & 1 & 1 & 0 & 0 & 0 & 1 & 0 & 0 & 0 & 0 & 0 & 1 & 0 & 1 & 0 & 0 \\
\hline Ammoph & 1 & 0 & 1 & 1 & 2 & 3 & 2 & 2 & 0 & 1 & 0 & 1 & 1 & 0 & 0 & 1 & 1 & 1 & 0 & 0 & 0 & 0 & 1 & 0 & 0 & 0 & 0 & 1 & 0 & 1 & 1 \\
\hline A barb & 0 & 1 & 1 & 1 & 1 & 3 & 4 & 3 & 0 & 1 & 0 & 1 & 1 & 1 & 0 & 1 & 1 & 1 & 0 & 0 & 0 & 1 & 0 & 1 & 0 & 0 & 1 & 0 & 1 & 0 & 0 \\
\hline A fatu & 0 & 1 & 1 & 1 & 1 & 3 & 4 & 3 & 0 & 1 & 0 & 1 & 1 & 1 & 0 & 1 & 1 & 0 & 0 & 0 & 0 & 1 & 0 & 1 & 0 & 0 & 1 & 0 & 1 & 0 & 0 \\
\hline A sati & 0 & 1 & 3 & 2 & 1 & 3 & 4 & 3 & 0 & 1 & 0 & 1 & 1 & 1 & 0 & 1 & 1 & 1 & 0 & 0 & 0 & 1 & 0 & 1 & 0 & 0 & 1 & 0 & 1 & 0 & 0 \\
\hline A ster & 0 & 1 & 1 & 1 & 1 & 3 & 4 & 3 & 0 & 1 & 0 & 1 & 1 & 1 & 0 & 1 & 1 & 0 & 0 & 0 & 0 & 1 & 0 & 1 & 0 & 0 & 1 & 0 & 1 & 0 & 0 \\
\hline Laguru & 1 & 0 & 1 & 4 & 2 & 2 & 1 & 1 & 1 & 0 & 0 & 0 & 1 & 1 & 0 & 1 & 1 & 1 & 0 & 0 & 0 & 1 & 0 & 1 & 1 & 0 & 1 & 0 & 1 & 0 & 0 \\
\hline P mino & 0 & 1 & 2 & 1 & 3 & 2 & 1 & 1 & 0 & 1 & 0 & 0 & 0 & 1 & 0 & 1 & 0 & 0 & 0 & 0 & 1 & 1 & 0 & 0 & 0 & 0 & 1 & 0 & 1 & 0 & 0 \\
\hline P para & 0 & 1 & 1 & 2 & 3 & 2 & 1 & 1 & 0 & 1 & 0 & 0 & 0 & 1 & 0 & 1 & 0 & 0 & 0 & 0 & 1 & 1 & 0 & 0 & 0 & 0 & 1 & 0 & 1 & 0 & 0 \\
\hline Ph pra & 1 & 0 & 4 & 4 & 2 & 1 & 3 & 2 & 0 & 1 & 0 & 0 & 1 & 1 & 0 & 0 & 1 & 0 & 1 & 1 & 0 & 1 & 0 & 1 & 1 & 0 & 1 & 0 & 1 & 1 & 0 \\
\hline $\mathrm{Ph}$ sub & 1 & 0 & 3 & 4 & 2 & 1 & 3 & 2 & 0 & 1 & 0 & 0 & 1 & 1 & 0 & 1 & 1 & 0 & 1 & 1 & 0 & 1 & 0 & 1 & 1 & 0 & 1 & 0 & 1 & 1 & 0 \\
\hline Po mar & 1 & 1 & 1 & 4 & 2 & 1 & 1 & 1 & 1 & 1 & 0 & 0 & 0 & 1 & 0 & 1 & 1 & 0 & 0 & 1 & 0 & 1 & 0 & 1 & 1 & 1 & 1 & 0 & 1 & 1 & 0 \\
\hline Po mon & 1 & 1 & 1 & 4 & 2 & 1 & 1 & 1 & 1 & 1 & 0 & 0 & 0 & 1 & 0 & 1 & 1 & 0 & 0 & 1 & 0 & 1 & 0 & 1 & 1 & 1 & 1 & 0 & 1 & 1 & 0 \\
\hline Po vir & 1 & 1 & 1 & 4 & 2 & 1 & 1 & 1 & 1 & 1 & 0 & 0 & 1 & 1 & 0 & 0 & 1 & 0 & 0 & 1 & 0 & 1 & 0 & 1 & 0 & 0 & 1 & 0 & 1 & 1 & 0 \\
\hline Rostra & 0 & 0 & 1 & 1 & 2 & 1 & 1 & 2 & 0 & 1 & 1 & 0 & 0 & 1 & 0 & 1 & 1 & 1 & 0 & 0 & 0 & 1 & 0 & 0 & 1 & 0 & 1 & 0 & 1 & 0 & 0 \\
\hline T glum & 0 & 0 & 1 & 1 & 3 & 2 & 1 & 1 & 0 & 1 & 0 & 1 & 0 & 1 & 0 & 1 & 1 & 1 & 0 & 0 & 0 & 1 & 0 & 1 & 0 & 0 & 1 & 0 & 1 & 0 & 0 \\
\hline $\mathrm{T}$ line & 1 & 0 & 1 & 3 & 3 & 2 & 4 & 3 & 0 & 1 & 1 & 1 & 0 & 1 & 0 & 1 & 1 & 1 & 0 & 0 & 0 & 1 & 0 & 1 & 0 & 0 & 1 & 0 & 1 & 0 & 0 \\
\hline
\end{tabular}

The sub-ordinate group 4 comprised three species; Alopecurus myosuroides, Trisetaria linearis and Ammophila arenaria. These species were moderately similar in unequal lanceolate glumes, 1-flowered spikelet and the presence of both straight and hooked hairs, while Ammophila arenaria differ in some characters from the other two species, which made it separated monophyletically from them, i.e. having 2-nerved lower glumes, the triangular stomatal subsidiary cells, presence of narrow elliptic silica bodies with pointed ends, in addition to the silica-cork cells
(Plate 1;3). The placement of Alopecurus myosuroides and Ammophila arenaria in one sub-group matches with previous classification systems (Tab. 1), while the appearance of Trisetaria linearis with them in one group is unusual. It is important to study the scattering of the two species of genus Trisetaria in two different sub-groups (1 and 4) using more characters.

The sub-ordinate group 5 included the four Avena species; A. barbata, A. fatua, A. sterilis and A. sativa. It is obvious from the dendrogram (Fig. 1) and the data matrix 
Tab. 5. Factor loadings of the 31 characters (C1-C31) on the first three principal components axes. Highest loadings in bold

\begin{tabular}{|c|c|c|c|c|}
\hline \multirow{3}{*}{ Characters } & \multirow{2}{*}{ Characters } & \multicolumn{3}{|c|}{ PCA Axes } \\
\hline & & 1 & 2 & 3 \\
\hline & Eigenvalue & 0.392 & 0.229 & 0.080 \\
\hline $\mathrm{C} 1$ & $\begin{array}{l}\text { No. of flowers } \\
\text { in spikelet }\end{array}$ & -0.562 & 0.418 & -0.026 \\
\hline $\mathrm{C} 2$ & $\begin{array}{c}\text { Similarity of } \\
\text { glumes in length }\end{array}$ & 0.135 & -0.005 & -0.459 \\
\hline C3 & Glume shape & -0.020 & 0.644 & 0.621 \\
\hline $\mathrm{C} 4$ & Glume apex & -0.664 & 0.673 & -0.230 \\
\hline C5 & Glume surface & -0.545 & -0.462 & 0.374 \\
\hline C6 & Glume length & 0.800 & -0.140 & -0.300 \\
\hline C7 & $\begin{array}{l}\text { Number of veins } \\
\text { in lower glume }\end{array}$ & 0.820 & 0.516 & 0.065 \\
\hline $\mathrm{C} 8$ & $\begin{array}{l}\text { Number of veins } \\
\text { in upper glume }\end{array}$ & 0.875 & 0.391 & -0.029 \\
\hline C9 & $\begin{array}{l}\text { Spiral thickening } \\
\text { of xylem vessels }\end{array}$ & -0.607 & 0.0198 & -0.350 \\
\hline $\mathrm{C} 10$ & $\begin{array}{l}\text { Annular thickening } \\
\text { of xylem vessels }\end{array}$ & 0.050 & -0.009 & 0.072 \\
\hline $\mathrm{C} 11$ & $\begin{array}{l}\text { Epidermal long } \\
\text { cells: parallel walls }\end{array}$ & 0.081 & -0.090 & 0.044 \\
\hline $\mathrm{C} 12$ & $\begin{array}{l}\text { Epidermal long cells; } \\
\text { parallel walls shape }\end{array}$ & 0.806 & -0.025 & -0.284 \\
\hline $\mathrm{C} 13$ & Bulliform cells & 0.439 & 0.546 & -0.073 \\
\hline $\mathrm{C} 14$ & $\begin{array}{c}\text { Stomatal } \\
\text { subsidiary cells }\end{array}$ & -0.148 & 0.219 & 0.030 \\
\hline $\mathrm{C} 15$ & Epidermal papillae & 0.163 & -0.032 & 0.235 \\
\hline $\mathrm{C} 16$ & Hooked prickle hairs & 0.320 & -0.443 & -0.149 \\
\hline $\mathrm{C} 17$ & Straight prickle hairs & 0.119 & 0.463 & -0.296 \\
\hline $\mathrm{C} 18$ & Macro hairs & 0.332 & -0.173 & -0.206 \\
\hline $\mathrm{C} 19$ & $\begin{array}{l}\text { Irregular bilobate } \\
\text { silica bodies }\end{array}$ & -0.286 & 0.423 & 0.633 \\
\hline $\mathrm{C} 20$ & Trilobate silica bodies & -0.703 & 0.465 & 0.075 \\
\hline $\mathrm{C} 21$ & $\begin{array}{l}\text { Elongate smooth } \\
\text { silica bodies }\end{array}$ & -0.001 & -0.410 & 0.394 \\
\hline $\mathrm{C} 22$ & Trapezoid silica bodies & -0.228 & 0.183 & -0.149 \\
\hline $\mathrm{C} 23$ & $\begin{array}{l}\text { Narrow elliptic } \\
\text { silica bodies }\end{array}$ & 0.150 & -0.219 & -0.030 \\
\hline $\mathrm{C} 24$ & $\begin{array}{l}\text { Side walls of } \\
\text { silica bodies }\end{array}$ & -0.058 & 0.597 & -0.385 \\
\hline $\mathrm{C} 25$ & $\begin{array}{l}\text { Silica bodies with } \\
\text { concave ends }\end{array}$ & -0.663 & 0.289 & 0.111 \\
\hline $\mathrm{C} 26$ & $\begin{array}{l}\text { Silica bodies with } \\
\text { convex ends }\end{array}$ & -0.495 & 0.118 & -0.440 \\
\hline $\mathrm{C} 27$ & $\begin{array}{l}\text { Silica bodies } \\
\text { with flat ends }\end{array}$ & -0.150 & 0.219 & 0.030 \\
\hline C28 & $\begin{array}{l}\text { Silica bodies with } \\
\text { pointed ends }\end{array}$ & -0.035 & -0.335 & 0.163 \\
\hline $\mathrm{C} 29$ & $\begin{array}{l}\text { Silica bodies }>3 \text { times } \\
\text { as long as width }\end{array}$ & -0.150 & 0.219 & 0.030 \\
\hline $\mathrm{C} 30$ & $\begin{array}{l}\text { Silica bodies }<3 \text { times } \\
\text { as long as width }\end{array}$ & -0.609 & 0.347 & 0.058 \\
\hline $\mathrm{C} 31$ & Silica-cork cells & 0.150 & -0.219 & -0.030 \\
\hline
\end{tabular}

(Tab. 4) that $A$. fatua and $A$. sterilis appeared very close to each other and seemed to be one species, that they were similar in all recorded characters, which needs further study using wider characters. At the same time, $A$. barbata appeared closer to them due to the characters similarity, except the presence of macrohairs, while, $A$. sativa differ from the other three species by the presence of macrohairs and elliptic acuminate glumes, so it appeared as monophyletic species.

The placement of all Avena representatives in one group matches with the classification systems constructed by Loskutov (2007), by studying the relationships of genomes of different Avena species at each ploidy level, and (Peng et al., 2010) through studying the evolution pattern of rDNA ITS in Avena and phylogenetic relationship of the Avena species.

PCA based on the 31 characters (Fig. 2) explained $68.2 \%$ of the total variation. Axis one explained $34.1 \%$, axis two $20.7 \%$, and axis three $13.4 \%$. It was evident that members of sub-ordinate groups 1 and 2 that comprised of Agrostis stolonifera, Rostraria cristata and Trisetaria glumacea, Phalaris minor and $P$. paradoxa were strongly correlated to differences in glume surface (C5). Members of sub-ordinate group (3) that comprised of Lagurus ovatus, Polypogon maritimus, $P$. monospeliensis and $P$. viridis, and the Phleum pratense and Ph. subulatum showed highly correlated to spiral thickening of xylem vessels (C9), silica bodies with concave ends (C25) and silica bodies with convex ends (C26). On the other hand, members of subordinate groups (4) and (5) showed high correlations with

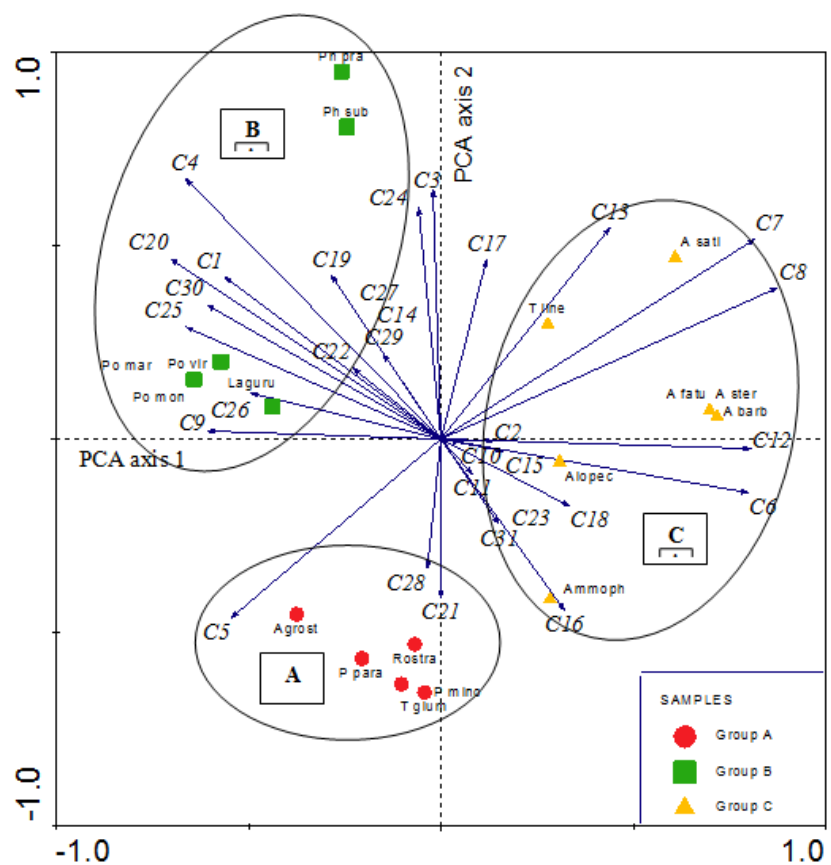

Fig. 2. Principal component analysis (PCA) of the studied species of Aveneae based on 31 morphological characters (arrows), together with their clusters (A, B and C). See Tab. 2 for abbreviations of species, and Tab. 3 for character abbreviations 

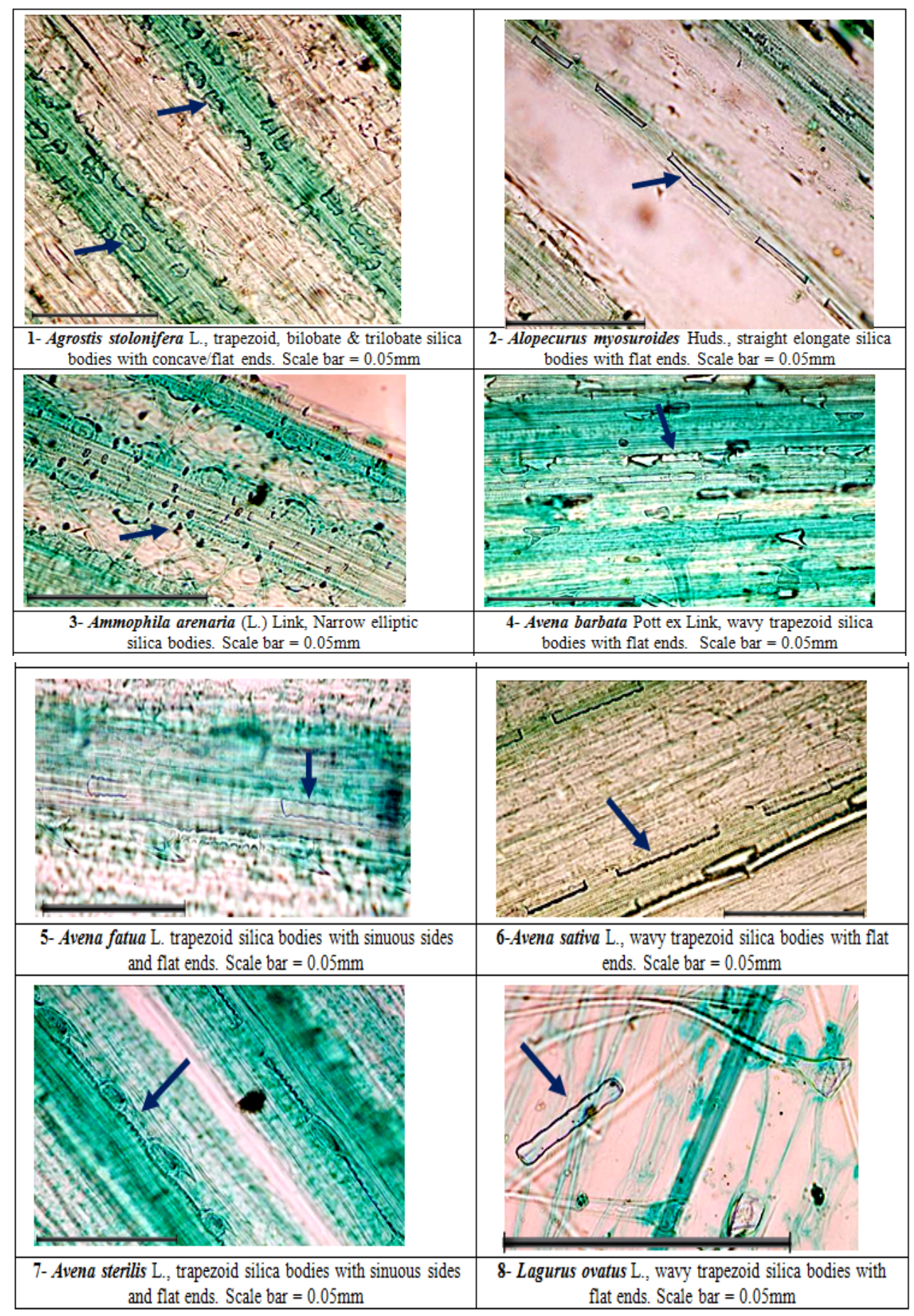

Plate 1. Light micrographs of the studied taxa of tribe Aveneae, showing their silica bodies structure

number of veins in lower glume (C7), epidermal long cells; parallel walls shape (C12) and bulliform cells (C13). Significant negative loadings in relation to PCA axis 1 were number of flowers in spikelets, glume apex and glume, spiral thickening of xylem vessels, trilobate silica bodies, silica bodies with concave ends, silica bodies with convex ends and silica bodies less than 3 times as long as width, while significant positive loadings included glume length, number of veins in lower glume, number of veins in upper glume, epidermal long cells; parallel walls shape and bulliform cells (Tab. 5). Along PCA axis 2, the significant negative loadings included glume surface, while the significant positive loadings included glume shape, glume apex, number of veins in lower glume, bulliform cells, straight prickle hair, trilobite silica bodies and side walls of silica bodies. 

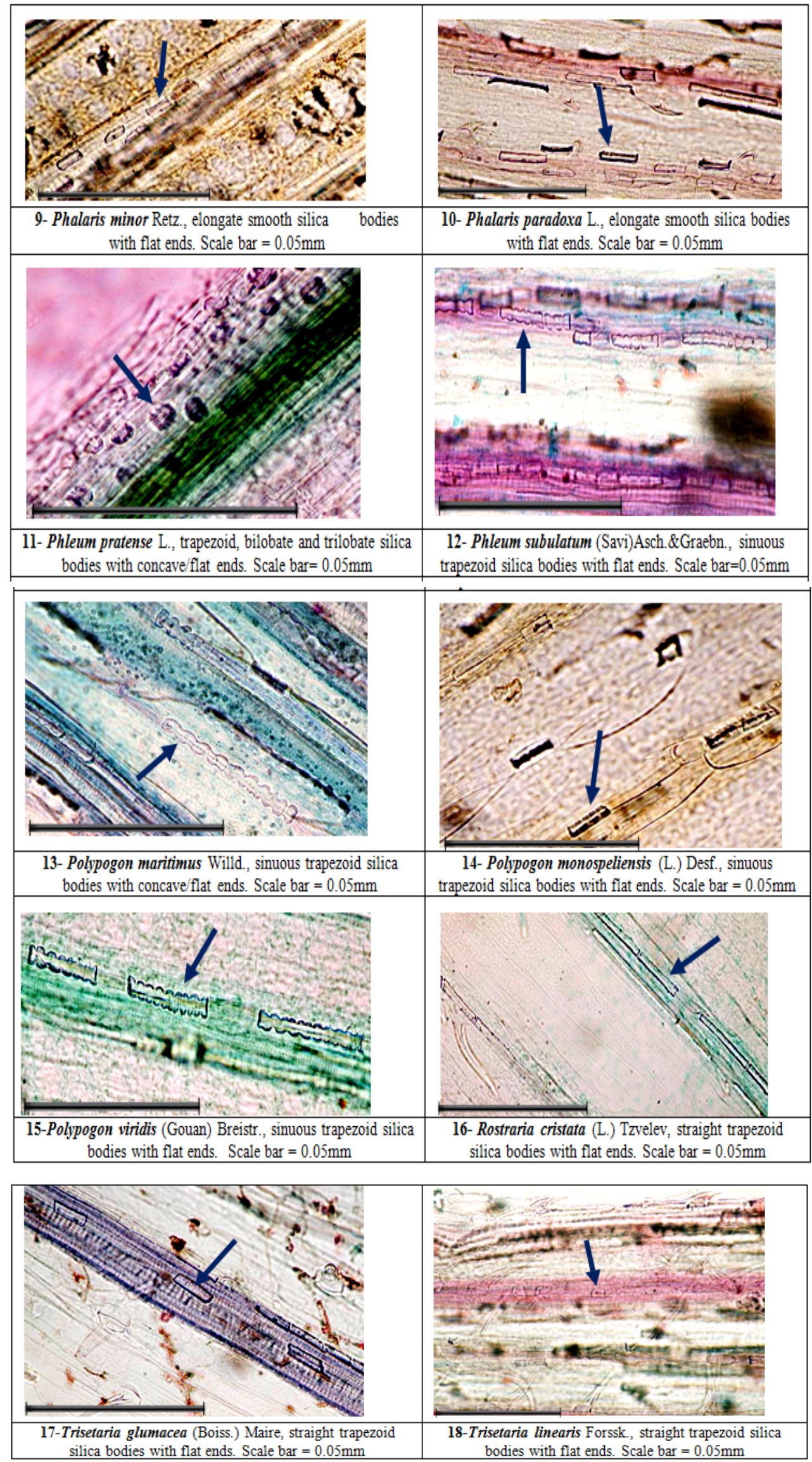

Plate 1. Light micrographs of the studied taxa of tribe Aveneae, showing their silica bodies structure (Continuos) 


\section{Conclusions}

In the present study, the total 31 characters recorded the morphology of glumes and the features of silica skeleton among 18 species of tribe Aveneae. Numerical methods were applied to study the relationship and the level of variation within and among these species. The relationships between silica skeleton morphologies and the taxa of tribe Aveneae have never been studied previously.

Metcalfe (1960) described several kinds of specialized cells (short cells) as: cork-cells containing silica bodies, stomata, and dermal appendages. The shape of the silica bodies formed in the short cells over the veins can be used to identify the subfamilies of the Gramineae and also some of the tribes (Piperno and Pearsall, 1998; Twiss et al., 1969). This evidence was confirmed here through the separation of the two Phleum species in an inner-group due to the presence of irregular bilobate silica bodies. In another case, the appearance of Ammophila arenaria as a monophyletic species in the sub-ordinate group 4, due to the differences in some characters from the other species, such as, the triangular silicified stomatal subsidiary cells and the presence of narrow elliptic silica bodies with pointed ends, in addition to the silica-cork cells.

The application of characteristics of leaf epidermis to classification and system evolution of tribe Aveneae was conducted by Xinming et al. (1998). The results of that study showed that characteristics of essential cells, such as size and shape of long cells, shape of short cells, as well as the distributions and shapes of macro hairs and prickle hairs, possess important value for classification of Aveneae. This evidence appeared obviously in our study by the presence of both straight and hooked hairs in Ammophila arenaria, which may be the reason of grouping it with the other two species in sub-group 4, despite of its monophyletic aspect.

Past intertribal hybridization events were advocated as a plausible explanation for the traditional misclassifications and the present existence of certain Avenae taxa with Poeae plastid genomes and vice versa (Soreng and Davis, 2000). The first phylogenetic study with a large sampling of Aveneae taxa was by Soreng and Davis (2000). Their combined analysis of plastid restriction site data and structural data resulted in a consensus topology suggested the placement of Aveneae within Poeae and recognized a series of subtribes of Aveneae that were later expanded by Soreng et al. (2003). The unstable and problematic classification of tribe Aveneae into a set of subtribes, may explains the unusual events in this study, such as: the placements of Agrostis stolonifera far from the sub-ordinate group 3, where included the majority of the Agrostideae representatives, that characterized by many characters as the 1-flowered spikelets. Another case is the scattered species of genus Trisetaria in two different sub-groups ( 1 and 4 ), which requires an extra study using wider range of parameters.
Acknowledgements

We are grateful to the curator of the Cairo University Herbarium (CAI) for supporting our study with dried specimens representing the selected species.

\section{References}

Ahmad F, Khan AM, Ahmad M, Arshad M, Zafar M, Khan K, Raja NI, Rehman Z (2011). Foliar epidermal anatomy as an aid to the identification of grasses in tribe Aveneae (subfamily Pooideae, Poaceae) from salt range of Pakistan. J Med Plants Res 5(1):81-87.

APG, Angiosperm Phylogeny Group III (2009). An update of the Angiosperm Phylogeny Group classification for the orders and families of flowering plants: APG III. Bot J Linn Soc 161:105-21.

Arimura S, Kanno I (1958). An investigation of plant opals (preliminary report). Kyushu Agronomy Research 11:97-109.

Ascherson PFA, Graebner KOPP (1898-1902). Mitteleuropaischen Flora, vol. Glumiflorae 1. Graminae. Wilhelm Engelmann, Leipzig, Germany, 795 p.

Barthlott W, Neinhuis C, Cutler D, Ditsch F, Meusel I, Wilhelmi H (1998). Classification and terminology of epicuticular waxes. Bot J Linn Soc 126:237-260.

Boulos L (2005). Flora of Egypt. Vol. 4: Monocotyledons. Al Hadara Publishing, Cairo, Egypt.

Bowdery DB, Hart D, Lentfer C, Wallis LA (2001). A universal phytolith key, 267-278 p. In: Colin JD, Meunier F (Eds.). Phytoliths: Applications in Earth Science and Human History. Balkema, Rotterdam.

Brown DA (1984). Prospects and limits of a phytolith key for grasses in the central United States. J Archaeol Sci 11:345368.

Cai LB, Wang SJ (1994). Studies on the evolutionary trends and mechanism of the constituent cells of the leaf epidermis in Poaceae. Acta Biologia Plateau Sinica 12:13-27.

Catala' NP, Kellogg EA, Olmstead RG (1997). Phylogeny of Poaceae subfamily Pooideae based on chloroplast ndhF gene sequences. Mol Phylogenet Evol 8:150-166.

Catala' NP, Torrecilla P, Lo' Pez Rodri'Guez JA, Olmstead R (2004). Phylogeny of the festucoid grasses of subtribe Loliinae and allies (Poeae, Pooideae) inferred from ITS and trnLF sequences. Mol Phylogenet Evol 31:517-541.

Chiapella J (2007). A molecular phylogenetic study of Deschampsia (Poaceae: Aveneae) inferred from nuclear ITS and plastid trnL sequence data: support for the recognition of Avenella and Vahlodea. Taxon 56:55-64.

Clark J (1960). Preparation of leaf epidermis for topographic study. Stain Technol 35-39.

Clayton WD (1981). Evolution and distribution of grasses. Ann Missouri Bot Gard 68:5-14.

Clayton W D, Renvoize SA (1986). Genera Graminae: grasses of the world. Royal Bot Gard Kew, London. Kew Bulletin. 
154 Additional series XIII.

Clayton WD (1975). Chorology of the genera of Gramineae. Kew Bulletin 30:111-132.

Conert HJ (1983-1992). Gramineae, 81-480 p. In: Conert HJ, Hamann U, Schultze-Motel W, Wagenittz G (Eds.). G. Hegi, Illustrierte Flora von Mitteluropa ed. 3,1(3) Parey, Hamburg.

Davila P, Clark LG (1990). Scanning electron microscopy survey of leaf epidermis of Sorghastrum (Poaceae) Andropogoneae. Am J Bot 77:499-511.

Davis JI, Soreng RJ (2007). A preliminary phylogenetic analysis of the grass subfamily Pooideae (Poaceae), with attention to structural features of the plastid and nuclear genomes, including an intron loss in GBSSI. Aliso 23:335-348.

Davis JI, Soreng RJ (1993). Phylogenetic structure in the grass family (Poaceae) as inferred from chloroplast DNA restriction site variation. Am J Bot 70:1444-1454.

Dogan M (1999). A Concise Taxonomic Revision of the Genus Alopecurus L. (Gramineae). Turk J Bot 23:245-262.

Edgar E (1998) Trisetum Pers. (Gramineae: Aveneae) in New Zealand. New Zeal J Bot 36(4):539-564.

El Rabey H ( 2008). Biochemical and Molecular Taxonomic Study on Some Egyptian Avena L. Taxa. Res J Cell \& Mol Biol 2(2):53-61.

Ellis RP (1979). A procedure for standardizing comparative leaf anatomy in the Poaceae. The epidermis as seen in surface view. Bothalia 12:641-679.

Fredlund GG, Tieszen LT (1994). Modern phytolith assemblages from the North American Great Plains. J Biogeogr 21:312-335.

GPWG, Grass Phylogeny Working Group (2001). Phylogeny and subfamilial classification of the grasses (Poaceae). Ann Missouri Bot Gard 88:373-457.

Grebenstein B, Röser M, Sauer M, Hembelen V (1998). Molecular phylogenetic relationships in Aveneae (Poaceae) species and other grasses as inferred from ITS1 and ITS2 rDNA sequences. Plant Syst Evol 213:233-250.

Grit W, Röser M (2006). Chromosomal localization and evolution of satellite DNAs and heterochromatin in grasses (Poaceae), especially tribe Aveneae. Plant Syst Evol 264(12):75-100.

Grit W, Elke D, Röser M (2009). Chromosome evolution in wild oat grasses (Aveneae) revealed by molecular phylogeny. Genome 52(4,1):361-380.

Hai-Ying M, Hua P, Yue-Hua W (2006). Morphology of leaf epidermis of Calamagrostis s.l. (Poaceae: Pooideae) in China. Acta Phytotaxonomica Sinica 44(4):371-392.

Honaine MFN, Zuco AF, Osterrieth ML (2006). Phytolith assemblages and systematic associations in grassland species of the south-eastern pampean plains. Argentina Annals of Botany 98:1155-1165.

Hsiao C, Chatterton NJ, Asay KH (1995). Molecular phylogeny of the Pooideae (Poaceae) based on nuclear rDNA (ITS) sequences. Theor Appl Genet 90:389-398.

Kovach WL (1999). MVSP - A Multivariate Statistical Package for Windows, version 3.1. Kovach Computing Services, Pentraeth, Wales, U.K.

Loskutov IG (2007). On evolutionary pathways of Avena species, Genet Resour Crop Evol, DOI 10.1007/s10722-0079229-2.

Mabberley DJ (2008). Mabberley's Plant-Book.: A portable dictionary of plants, their classification and uses. Third edition, Cambridge University Press.: vii-xviii, 1-1021

Macfarlane TD (1987). Poaceae subfamily Pooideae, 473 p. In: Sorderstrom R, Hilu KW, Campbell CS, Barkworth ME (Eds.). Grass systematics and evolution. Smithsonian Institution, Washington, D.C., USA.

Macfarlane TD, Watson L (1980). The circumscription of Poaceae subfamily Pooideae, with notes on some controversial genera. Taxon 29:645-666.

Macfarlane TD, Watson L (1982). The classification of Poaceae subfamily Pooideae. Taxon 31:178-203.

Madella M, Alexandre A, Ball T (2005). International Code for Phytolith Nomenclature 1_0. Ann Bot 96:253-260.

Maire R, Guinochet M, Faurel L (1953). Flore de l'Afrique du Nord, vol. 2. P. Lechevalier, Paris, France, 374 p.

McCune B (1997). PC-ORD version 5, for Windows. Specifications. http://home.centurytel.net/ mjm/winspecs.htm

Meija T, Bisbey FA (2003). Silica bodies and hooked papillae in lemmas of Melica species (Gramineae: Pooideae). Bot J Linn Soc 141:447-463.

Metcalfe CR (1960). Anatomy of the monocotyledons, $731 \mathrm{p}$. In: Gramineae I (Ed.). London, Oxford University Press.

Mitra S, Mukherjee SK (2005). Ethnobotanical usages of grasses by the tribals of West Dinajpur district, West Bengal. Indian J Tradit Know 4(4):396-402.

Mulholland SC (1989). Phytolith shape frequencies in North Dakota grasses: a comparison to general patterns. J Archaeol Sci 16:489-511.

Mulholland SC, Rapp G (1992). A morphological classification of grass silica bodies, 65-89 p. In: Rapp G, Mulholland SC (Eds.). Phytolith systematics. New York, Plenum Press.

Nadot S, Bajon R, Lejeune B (1994). The chloroplast gene rps4 as a tool for the study of Poaceae phylogeny. Plant Syst Evol 191:27-38.

Palmer PG, Tucker AE (1981). A scanning electron microscope survey of the epidermis of East African Grasses. Smithson Contrib Bot 49:1-84.

Palmer PG, Jones SG, Hutchison S (1985). A scanning electron microscope survey of the epidermis of east African Grasses 3. Smithson Contrib Bot 55:1-136.

Peng YY, Baum BR, Ren CZ, Jiang QT, Chen, GY, Zheng YL, Wei YM (2010). The evolution pattern of rDNA ITS in Avena and phylogenetic relationship of the Avena species (Poaceae: Aveneae). Hereditas 147:183-204. 
Pereira MP, Pérez GE, Balbuena ES (2007). European Sweet Vernal Grasses (Anthoxanthum: Poaceae, Pooideae, Aveneae): A Morphometric Taxonomical Approach. Syst Bot 32(1):43-59.

Piperno DR (1988). Phytolith analysis: An archaeological and geological perspective. San Diego, Academic Press.

Piperno DR, Pearsall DM (1998). The silica bodies of tropical American grasses: morphology, taxonomy, and implications for grass systematics and fossil phytolith identification. Annals of the Smithsonian Institution 85:1-40.

Prat H (1960). Vers une classification naturelle des gramine' es. Bulletin de la Socie' te ' Botanique de France 107:32-79.

Quintanar A, Castroviejo S, Catal P (2007). Phylogeny of the tribe Aveneae (Pooideae, Poaceae) inferred from plastid trnT$F$ and nuclear ITS sequences. Am J Bot 94:1554-1569.

Randall JL, Hilu KW (1986). Biosystematic studies of North American Trisetum spicatum (Poaceae). Syst Bot 11(4):567578.

Rodionov AV, Tyupal NB, Kim EC, Machs EM, Lokustov IG (2005). Genome composition of the autotetraploid oat species Avena macrostachya determined by comparative analysis of the ITS1 and ITS2 sequences: on the oat karyotype evolution on early events of oats species divergence. Russ J Genet 41(1):1-11.

Saarela JM, Liu Q, Peterson PM, Soreng RJ, Paszk B (2010). Phylogenetics of the Grass 'Aveneae-Type Plastid DNA Clade' (Poaceae: Pooideae, Poeae) Based on Plastid and Nuclear Ribosomal DNA Sequence Data, diversity, phylogeny, and evolution in the monocotyledons.

Schaffner JH (1912). A Revised Taxonomy of the Grasses. The Ohio Naturalist 11(5):490-493.

Scholz H (1999). Short notes on Phleum sect. Achnodon (Gramineae). Willdenowia 29(11-12):45-49

Soreng RJ, Davis JI (2000). Phylogenetic structure in Poaceae subfamily Pooideae as inferred from molecular and morphological characters: misclassification versus reticulation, 6174 p. In: Jacobs SWL, Everett JE (Eds.). Grasses: Systematics and Evolution.

Soreng RJ, Davis JI, Voionmaa MA (2007). A phylogenetic analysis of Poaceae tribe Poeae sensu lato based on morphological characters and sequence data from three plastid-encoded genes: evidence for reticulation, and a new classification for the tribe. Kew Bulletin 62:425-454.
Soreng RJ, Davis JI, Doyle JJ (1990). A phylogenetic analysis of chloroplast DNA restriction site variation in Poaceae subfam. Pooideae. Plant Syst Evol 172:83-97.

Soreng RJ, Peterson PM, Davidse G, Judziewicz EJ, Zuloaga FO, Filgueiras TS, Morrone O (2003). Catalogue of New World grasses (Poaceae). IV. Subfamily Pooideae. Contributions from the United States National Herbarium 48:1-725.

Stebbens GL (1956). Cytogenetics and evolution of the grass family. Am J Bot 43:890-905.

Stebbins GL, Crampton B (1961). A suggested revision of the grass genera of temperate North America. Recent Advances in Botany 1:133-145.

Strivastava AK (1978). Study of leaf epidermis in the genus (Gramineae). J Indian Bot Soc 37:155-160.

Theunissen JD (1994). A method for isolating and preparing silica bodies in grasses for scanning electron microscopy. Biotech Histochem 69(5):291-294.

Tutin TG, Heywood VH, Burges NA, Moore DM, Valentine DH, Walters SM, Webb DA (1980). Flora Europaea, vol. 5. Cambridge University Press, Cambridge, UK.

Twiss PC, Suess E, Smith RM (1969). Morphological classification of grass phytoliths. Soil Science Society of America Proceedings 33:109-115.

Tzvelev NN (1976). Zlaki SSSR. Nauka Publishers, Leningrad, Russia. (English translation: 1983). Grasses of the Soviet Union. Amerid Publishing, New Delhi, India, 1196 p.

Tzvelev NN (1989). The system of grasses and their evolution. Botanical Review 55:141-204.

Watson L, Dallwitz MJ (1992). The grass genera of the world. CAB International Wallingford, Oxon, UK, $1081 \mathrm{p}$.

Xinming X, Wanli M, Li Y, Ruiping H (1998). Application of characteristics of leaf epidermis to classification and system evolution of tribe Aveneae. Journal of Inner Mongolia Normal University, Natural Science, Edition (1). 